\title{
THE FOETAL EPENDYMA OF CEREBRAL VENTRICLES IN SHEEP AND GOAT. THE THIRD CEREBRAL VENTRICLE IN THE LIGHT AND SCANNING ELECTRON MICROSCOPE
}

\author{
V. RAJTOVÁ \\ Department of Anatomy and Histology, University of Veterinary Medicine, Košice, Slovak Republic \\ Received July 7, 1999 \\ Accepted October 25, 1999 \\ Abstract \\ Rajtová V.: The Foetal Ependyma of Cerebral Ventricles in Sheep and Goat. The Third \\ Cerebral Ventricle in the Light and Scanning Electron Microscope. Acta Vet. Brno 68, 1999: \\ 241-245. \\ The study of the ependyma of the third cerebral ventricle in 35 sheep foetuses and 16 goat \\ foetuses using a histological method, Golgi-Cox impregnation and scanning electron microscope \\ has revealed that the 3-4 layered ependyma (between days 40 and 50 of development) changes \\ through the pseudo-layered (up to day 130) in the typical one-layered ependyma (not long before \\ the birth). The external morphology of foetal ependymal cells is very variable. This is related to the \\ change of their location and gradual alteration. Remains from the foetal period can still be seen in \\ 2-month-old lambs in the region of the upper third cerebral ventricle. In the region of the third \\ cerebral ventricle between days 50 and 130 a co-arctation is formed, where many foetal ependymal \\ cells are mitotically active. The surfaces of the apical membranes of proximal processes as well as \\ the bodies of foetal ependymal cells, except for cilia, are covered with microvilli and spherical \\ secretory protrusions.
}

Central nervous system, third cerebral ventricle, sheep, goat, ependymal cells, co-arctation, migration, foetuses

The postnatal ependyma of the third cerebral ventricle in mammals is formed, above all, by one layer of cuboidal to cylindrical ependymocytes, and only in certain places (e.g. on the inner surface of the eminentia mediana) also flattened ependymal cells. In some mammals, certain differences have already been found under the light microscope, in the ependymal structure, especially close above the recessus infundibuli, which were related with sex differentiation (Kumar 1968 in macaques; Rajtová 1985 in adult sheep). Some authors have reported more types of ependymal cells on the basis of their external morphology or topography (Westergaard 1970; Mitro 1976, 1987; Milhouse 1971; Staníková et al. 1980), Schachenmayr (1967), Mitro and Schiebler (1972), Stensaas and Gilson (1972), Haase (1980), Felten et al. (1981) described both the foetal and neonatal ependyma of cerebral ventricles using the light microscope in different species of mammals, above all in laboratory rodents, but also in man. Not only the changes in the external morphology of cerebral ventricles as a whole were studied in the laboratory but also in some domesticated mammals (Fitzgerald 1961; Böhme and Franz 1967; Haase 1980; Lignereux et al. 1987, 1991). The data on the prenatal lining of cerebral ventricles using the light microscope in farm animals are not available in the literature.

The aim of the work is to deal with the study of foetal ependyma and its changes in the structure in small ruminants within the whole ventricular system and to observe the prenatal differences in its structure between sheep and goat. In the first part, we would like to pay attention to the ependyma in the region of the third cerebral ventricle.

Address for correspondence:

Prof. MVDr. Viera Rajtová, DrSc.

Prof. MVDrtment Ve Anatomy and Histology

Department of Anatomy and Histology

Komenského 73,041 81 Košice, Slovak Republic
Phone: +421956229924

Fax: + +421956323666

http://www.vfu.cz/acta-vet/actavet.htm 


\section{Materials and Methods}

Thirty five sheep foetuses and sixteen goat foetuses of both sexes with crown-rump length from 39 to $439 \mathrm{~mm}$, corresponding to the period between days 40 and 145 of prenatal development, were used for the study in the light microscope. In addition, the brains of four 2-month-old lambs were used for comparison.

The material was processed as follows:

1. Twenty four brains of sheep foetuses and twelve of goat foetuses were perfused with $3 \%$ formaldehyde solution and after being embedded in paraffin, the $7 \mu \mathrm{m}$ thick transverse sections were stained with haematoxylineosin and cresyl violet.

2. Samples from the ventricular system region coming from 8 sheep foetuses, 4 goat foetuses and four 2-monthold lambs were impregnated by the Golgi-Cox method (Gabe 1976) and after rapid embedding in celloidin they were sectioned to $20-30 \mu \mathrm{m}$ thick sections.

3 . The brains of freshly obtained 6 sheep foetuses were perfused with a phosphate buffer $(0.2 \mathrm{~mol} / \mathrm{l})$ and Karnovsky solution through the $a$. carotis communis. After rinsing the samples were fixed with $3 \%$ glutaraldehyde solution in cacodylate buffer $(0.2 \mathrm{~mol} / \mathrm{l})$. Then, samples were processed by the method of Murakami et al. (1977), dried by the method of the critical point, and after coating with gold, examined using scanning electron microscope JEOL.

\section{Results}

Study under the light microscope

The ependyma between days 40 and 44 of development is formed by 3-4 cellular layers, only in some places, e.g. in flexures (habenule region) also by more cellular layers. The space of the third cerebral ventricle at this time is wide, because the bilateral thalami optici are not yet connected by the adhesio interthalamica. On day 50 of development when the adhesio interthalamica is already formed, the space of the third cerebral ventricle is considerably narrower and contralateral walls, especially above the recessus infundibuli, form an incomplete symphysis, co-arctation (Plate VII, Figs 1,2) which is released approximately after day 130. In the co-arctation region in the small ruminant foetuses, a frequent occurrence of mitoses was found (Plate VII, Figs 3 A, B). Between days 50 and 130, an apparent sulcus lateralis stretches in the region in front of the adhesio interthalamica in contralateral walls.

On days 56-60, the ependyma is formed by 2 irregularly arranged rows of cells (it is a case of a pseudo-layered arrangement persisting approximately until day 130). In this period, the ependymal lining of the inner surface of the eminentia mediana is formed only by one layer of typically flattened cells. One-layered cuboidal to cylindrical ependyma may be recorded shortly before and after birth.

In one 57-old-day male goat foetus, the ependymal cells in the region of co-arctation were arranged into extra regular 4-5 rows (Plate VII, Fig. 4).

Differently large abundant spherical protrusions, very clearly visible also under the light microscope, were a part of the third cerebral ventricle ependyma in both small ruminant foetuses during the whole observed foetal period (Plate VIII, Fig. 5).

\section{Golgi-Cox impregnation}

After Golgi-Cox impregnation in all the studied small ruminant foetuses independent of sex or age, the external morphology of ependymal cells region indicated to a great variability. Various developmental forms can be found side by side - from migrating ependymoblasts to the forms suggesting postnatal developmental ependymal cells. Migrating ependymoblasts (Plate VIII, Fig. 6 A, B) have round to irregularly oval bodies from which one proximal and one basal process protrude. The length of processes is shortened depending on their distance from the ventricular wall and the degree of cellular maturity. The proximal process encroaches in the third ventricle lining. The body surface of ependymoblasts and both their processes are covered with abundant lamellae (Plate VIII, Fig. $6 \mathrm{~B}, \mathrm{C})$. Both processes are shortened by migration and maturation of foetal ependymal cells, lamellar projections become shorter and cellular body positions change; it makes the 
foetal ependyma pseudo-layered. After the setting of almost mature cells into the ependymal row, the proximal processes are missing, the original longer basal process (except of tanycytes) is supplemented with 1 or more short, thin often ramifying processes. Traces of foetal ependymal cells, especially in the upper part of the third ventricle were also observed in 2-month-old lambs.

Study by scanning electron microscope confirms that in small ruminant foetuses, 70 and more days old, the arrangement of foetal ependymal cells is pseudo-layered, and that their external morphology and position are variable (Plate VIII, Fig. 7, Plate IX, Fig. 8). Foetal ependymal cells have very short and wide proximal processes which are typical of the developmental stage of these cells before their arrangement into a definitive ventricular lining layer (Plate IX, Fig. 9 A, B). Despite the fact that such cells are still not mature, the apical membranes of their proximal processes are covered with low fibrous microvilli and tiny spherical protrusions in addition to cilia.

\section{Discussion}

The results of our study indicate that during the foetal period of small ruminants, both the shape of the third cerebral ventricle and the structure of the ependymal cells of the ventricular wall change. Until approximately day 50 of development, due to the absence of the adhesio interthalamica the third cerebral ventricle is wide, but after the formation of the above connection at certain sites, it becomes narrow to such degree that a temporary connection of the contralateral ependymal walls - co-arctation - appears, which in laboratory rodent foetuses are reported by Schachenmayr (1967), Westergaard (1970), Mitro (1976) and others. In the small ruminant foetuses under study, a frequent occurrence of ependymal cell mitoses was recorded only in the co-arctation region. Moreover, Flyger and Hjelmquist (1959), Stensaas and Gilson (1972), Felten et al. (1981) reported the mitotic activity of ependymal cells in various regions of the ventricular system.

The Golgi-Cox study, unlike routine histology, has shown that the external morphology and position of foetal ependymal cells in sheep and goat are variable, which is related to their migration and gradual maturation. This process does not finish for some time after birth, because the persistence of certain foetal signs may also be observed in 2-month-old lambs (perhaps older individuals). It is probably one of the causes of shape variability not only in prenatal but also postnatal ependymal cells, which has led some authors to attempt their typing (Milhouse 1971; Burnett and Felten 1981; Fernández-Llebrez et al. 1981; Rajtová 1987).

Study in scanning electron microscope has confirmed the pseudo-layered arrangement of foetal ependymal cells between days 50 and 130 of development, which had also been observed in the light microscope. Not long before birth and in the postnatal period, the ependyma is typically formed by a single layer. Migrating forms of foetal ependymal cells in our sheep and goat foetuses are characterized by the presence of two processes: proximal and basal. Similar developmental types of ependymal cells have been found in neonatal rabbits also by Stensaas and Gils on (1972) and they termed them as bipolar cells.

Abundant, spherical protrusions, varying in size, confirmed by routine histological study as well as in the scanning electron microscope, were a part of the ependymal surface of the third cerebral ventricle of both small ruminants. Similar protrusions in different species of mammals were described by Kumar (1988), Knowles (1969), Schwanitz (1969), Hannah and Geber (1972), Schechter and Weiner (1972), Coates (1973), Booz (1975), Scott et al. (1975), Shioda et al. (1977). Most of the authors consider these structures as a secretory product or a symptom of an active secretory process of ependymal cells with a potential specific effect. However, they may also represent metabolic products because the CNS has not the right lymph drainage as in other mammals. 
During the foetal period (57-day-old male goat foetus), unlike sheep foetuses, close above the recessus infundibuli, 4-5 regular layers of the ependymal cells were recorded. This was the only difference recorded in our study in the structure of the foetal ependyma between sheep and goat.

\section{Fetálna ependymová výstielka mozgových komôr u plodov ovce a kozy. Tretia mozgová komora vo svetelnom a riadkovacom elektrónovom mikroskope}

Štúdiom ependymu tretej mozgovej komory u 35 plodov ovce a 16 plodov kozy za použitia bežnej histologickej metódy, Golgi-Coxovej impregnácie a štúdia v riadkovacom elektrónovom mikroskope bolo zistené, že 3-4 vrstvový ependym (asi do 50. dňa vývoja) sa cez pseudovrstvový (do 130. dňa) mení na typický jednovrstvový (krátko pred a po narodení). Vonkajšia morfológia fetálnych ependymových buniek je velmi variabilná, čo súvisí so zmenou ich polohy a postupnou premenou. Ešte u 2-mesačných jahniat je možné pozorovat zbytky z fetálneho obdobia. Medzi 50. a 130. dňom je vytvorená koarktácia, v mieste ktorej mnohé fetálne ependymové bunky sú mitoticky aktívne. Povrch apikálnych membrán proximálnych výbežkov rovnako ako tiel fetálnych ependymových buniek okrem cílií nesie aj mikroklky a sférické (sekrečné) protrúzie.

\section{References}

BOOZ, K. H. 1975: Secretory phenomena at the ependyma of third ventricle of the third ventricle of the embryonic rat. Anat. Embryol. 147: 143-159

BÖHME, G., FRANZ, B. 1967: Binnenräume des Gehirns von Ratte und Maus. Acta Anat. 68: 199-206

BURNETT, B. T., FELTEN, D. L. 1981: Aquaeductal tanycytes in the rabbit brain: A Golgi study. Anat. Rec. 200: 337-347

COATES, P. W. 1973: Supraependymal cells and surface specializations of the floor of monkey third ventricle. Anat. Rec. 175: 294

FELTEN, D. L., CUMMINGS, J. P., BURNETT, B. T. 1981: Ontogeny of caudal fourth ventricular tanycytes in the rabbit brain. A Golgi study. Anat. Rec. 200: 321.330

FERNÁNDEZ-LLEBREZ, P., BECERRERA, F., MARÍN-GIRÓN, F. 1981: Histological study of the ependyma of the hypothalamic third ventricle in the water snake, Natrix maura (L.). Z. mikrosk.-anat. Forsch. 95: 22-32

FITZGERALD, T.C. 1961: Anatomy of cerebral ventricles of domestic animals. Vet. Med. 56: 38-45

FLYGER,G., HJELMQUIST, U. 1959: Ependymal cell migration from the Sylvian aquaeduct in fetuses and newborns. Anat. Rec. 135: 313-319

GABE, M. 1976: Histological Technics. Springer New York, Heidelberg, Berlin 1106 p.

HAASE, J. 1980: Die Embryonal - und Fetalentwicklung bei Haussäugetieren: Ventrikulographische Unterssuchungen. Inaug. Diss., Freiburg 85 p.

HANNAH, R. S., GEBER, W. 1972: Specializations of the ependyma in the third ventricle of the developing hamster. Am. J. Anat. 135: 597-603

KNOWLES, F. R. S. 1969: Ependymal secretion, especially in the hypothalamic region. J. Neurovisceral Relat. Suppl., 9: $97-100$

KUMAR, T. C. A. 1968: Sexual differences in the ependyma lining of the third ventricle in the area of anterior hypothalamus of adult rhesus monkeys. Z. Zellforsch. 90: 20-36

LIGNEREUX, Y., FARGEAS, J., MARTY, M. H., BÉRNARD, P. 1987: Cerebral ventricles of the Friesian cow (Bos taurus L.) Conformation, relations and stereotaxic topography. Acta Anat. 128: 89-92

LIGNEREUX, Y., REGODON, S., MARTY, M.-H., FRANGO, A., BUBIEN, A. 1991: Encephalic ventricles of the ewe (Ovis aries L.): Conformation, relations and stereotaxic topography. Acta Anat. 141: 82-84

MILHOUSE, O. E. 1971: A Golgi study of third ventricle tanycytes in the adult rodent brain. Z. Zellforsch. 121: $1-13$

MITRO, A., SCHIEBLER, T. H. 1972: Über die Entwicklung regionaler Unterschiede im Ependym des 3. Ventrikels der Ratte. Anat. Anz. 132: 1-9

MITRO, A. 1976: The ependyma of the rat brain ventricle system (in Slovak). Veda, SAV, Bratislava $145 \mathrm{p}$.

MURAKAMI, T., YAMAMOTO, K., ITOSHIMA, T. 1977: Modified tannin-osmium conductive method for noncoated SEM specimens and application to microsection SEM of spleen. Arch. histol. Jap. 40: 35-40

RAJTOVÁ, V. 1987: The ependyma of sheep. IV. The ependymal cells of the third cerebral ventricle: A Golgi study. Z. mikrosk.-anat. Forsch. 101: 659-668

SCOTT, D. E., KROBISCH-DUDLEY, G., PAULL, W.K., KOZLOWSKI, G. P., RIBAS, J. 1975: The primate median eminence. I. Correlative scanning-transmission electron microscopy. Cell Tissue Res. 162: 61-73 
SCHACHENMAYR, W. 1967: Über die Entwicklung von Ependym und Plexus chorioideus der Ratte. Z. Zellforsch. 77: 25-63

SCHECHTER, J., WEINER, R. 1972: Ultrastructural changes in the ependymal lining of the median eminence following the intraventricular administration of catecholamine. Anat. Rec. 172: 643-650

SHIODA, S., HONMA, Y., HOSOYA, Y. 1977: Scanning electron microscopy of the third ventricular wall in the lamprey, Lamperta japonica. Arch histol. Jap. 40: 41-49

SCHWANITZ, W. 1969: Die topographische Verteilung supraependymaler Strukturen in den Ventrikeln und Zentralkanal des Kaninchengehirns. Z. Zellforsch. 100: 536-551

STANÍKOVÁ, A., ARENDARČ́K, J., MARAČEK, I. 1980: Segmental localizations of the types of the ependyma of third brain ventricle of the sheep. Vet. Med. Praha 25: 705-715

STENSAAS, L., GILSON, B. C. 1972: Ependymal and subependymal cells of the caudato-pallial junction in the lateral ventricle of the neonatal rabbit. Z. Zellforsch. 132: 297-322

WESTERGAARD, E. 1970: The lateral cerebral ventricles and their ventricular walls. Andelsborgtrykkerier, Odense, $216 \mathrm{p}$. 
Plate VII

Rajtová, V.: The Foetal Ependyma...pp. 241-245
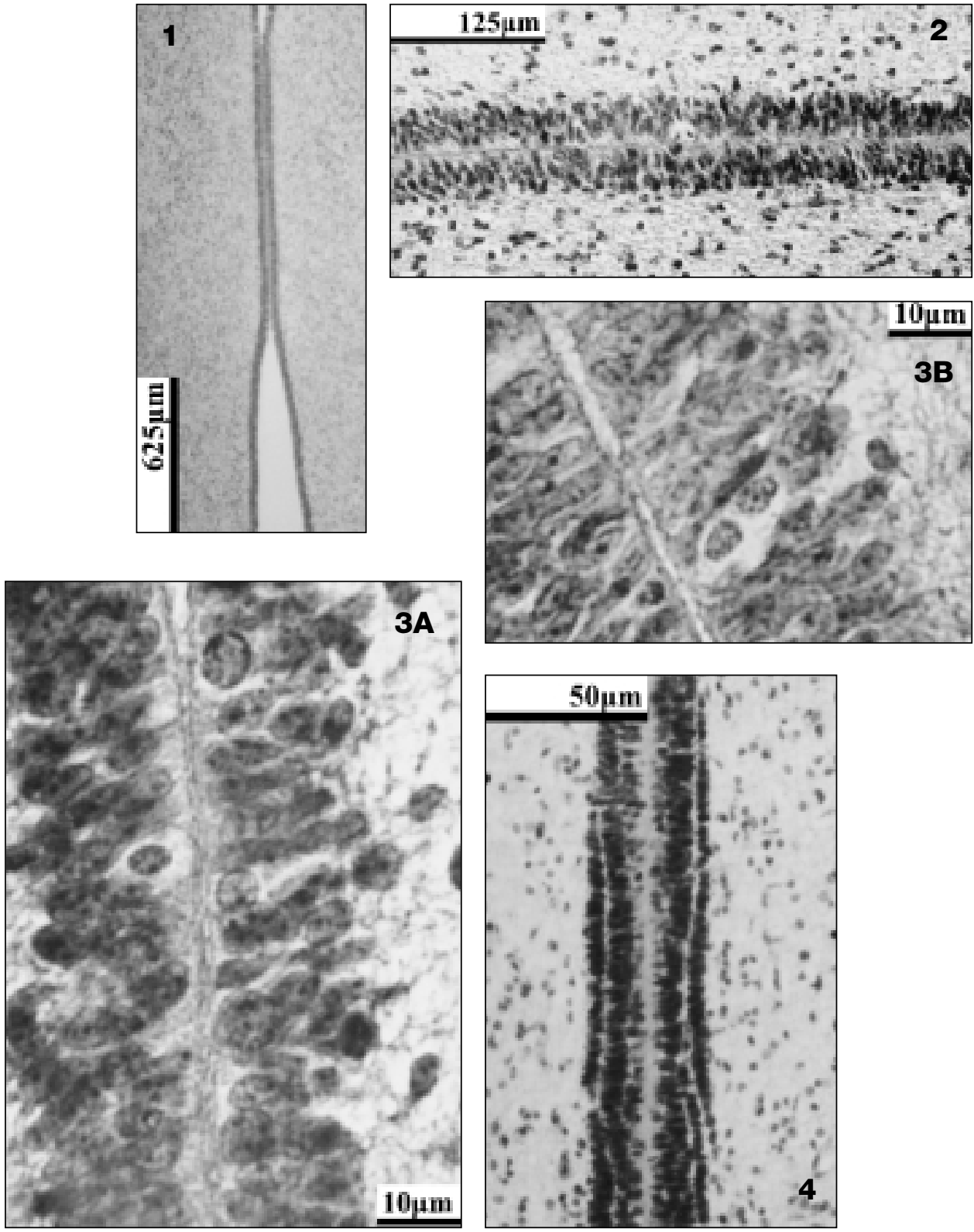

Fig. 1. A cross section through the third cerebral ventricle under the AIT at the place of co-arctation. 62 day-old sheep foetus. Haematoxylin-eosin.

Fig. 2. Part of the ependyma from the site the of co-arctation of the third cerebral ventricle. 70-day-old sheep foetus. Haematoxylin-eosin.

Fig. 3. Detail of the site of the co-arctation of the third cerebral ventricle with some mitotically active ependymal cells. Haematoxylin-eosin.

A. 70-day-old sheep foetus, B. 70-day-old goat foetus.

Fig. 4. Part of the ependymal lining of the third cerebral ventricle with abundant superficial spherical protrusions. 70-day-old goat foetus. Haematoxylin-eosin 
Plate VIII
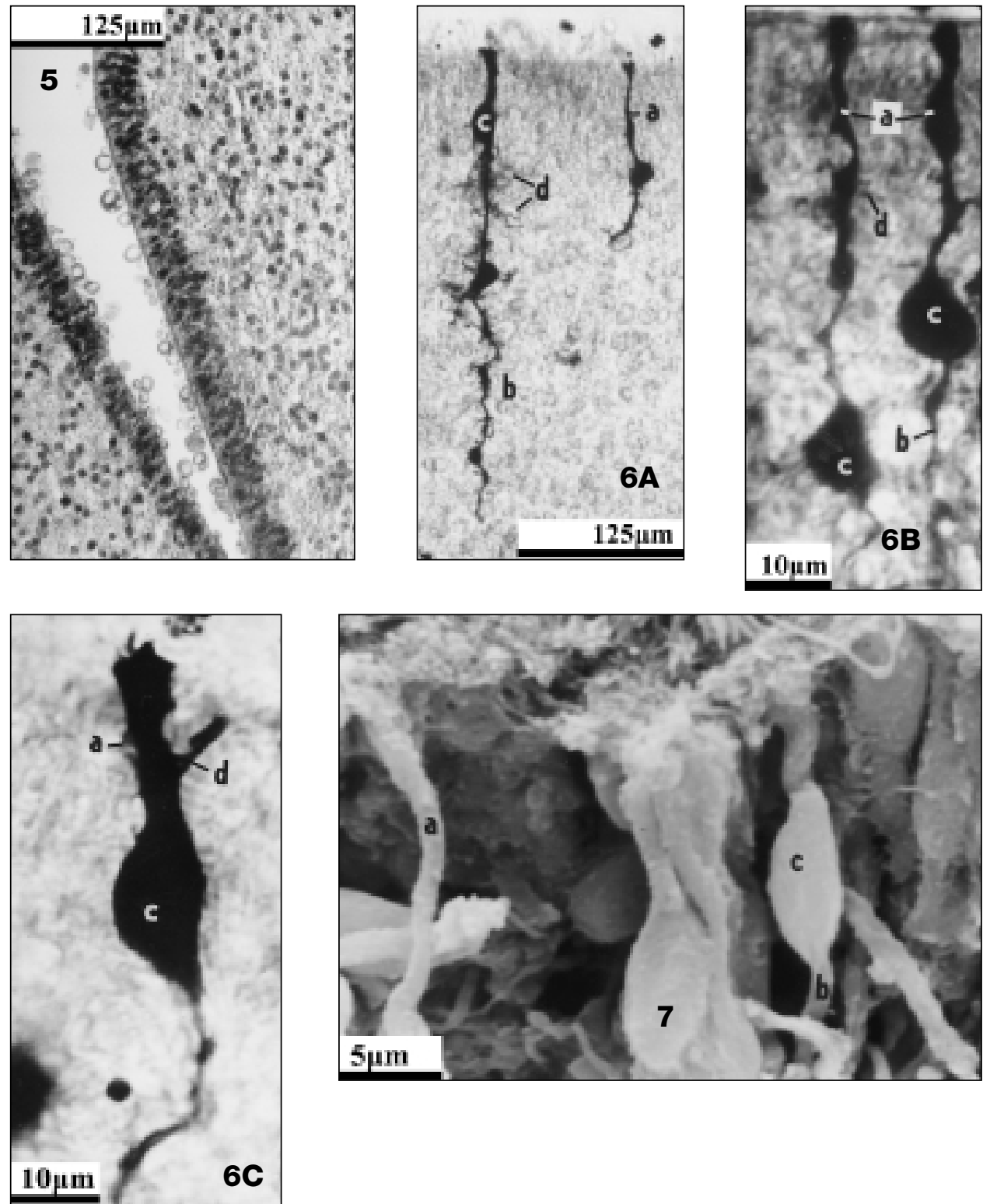

Fig. 5. Variable external morphology and position of migrating foetal ependymal cells from the third cerebral ventricle in a 100-day-old sheep foetus. Golgi-Cox impregnation.

Fig. 6. A, B, C. Pseudo-layered arrangement of the ependymal cells from the third cerebral ventricle in a 90-dayold sheep foetus.

Fig. 7. Pseudo-layered arrangement of the ependymal cells from the third cerebral ventricle in a 95-day-old goat foetus. 
Plate IX
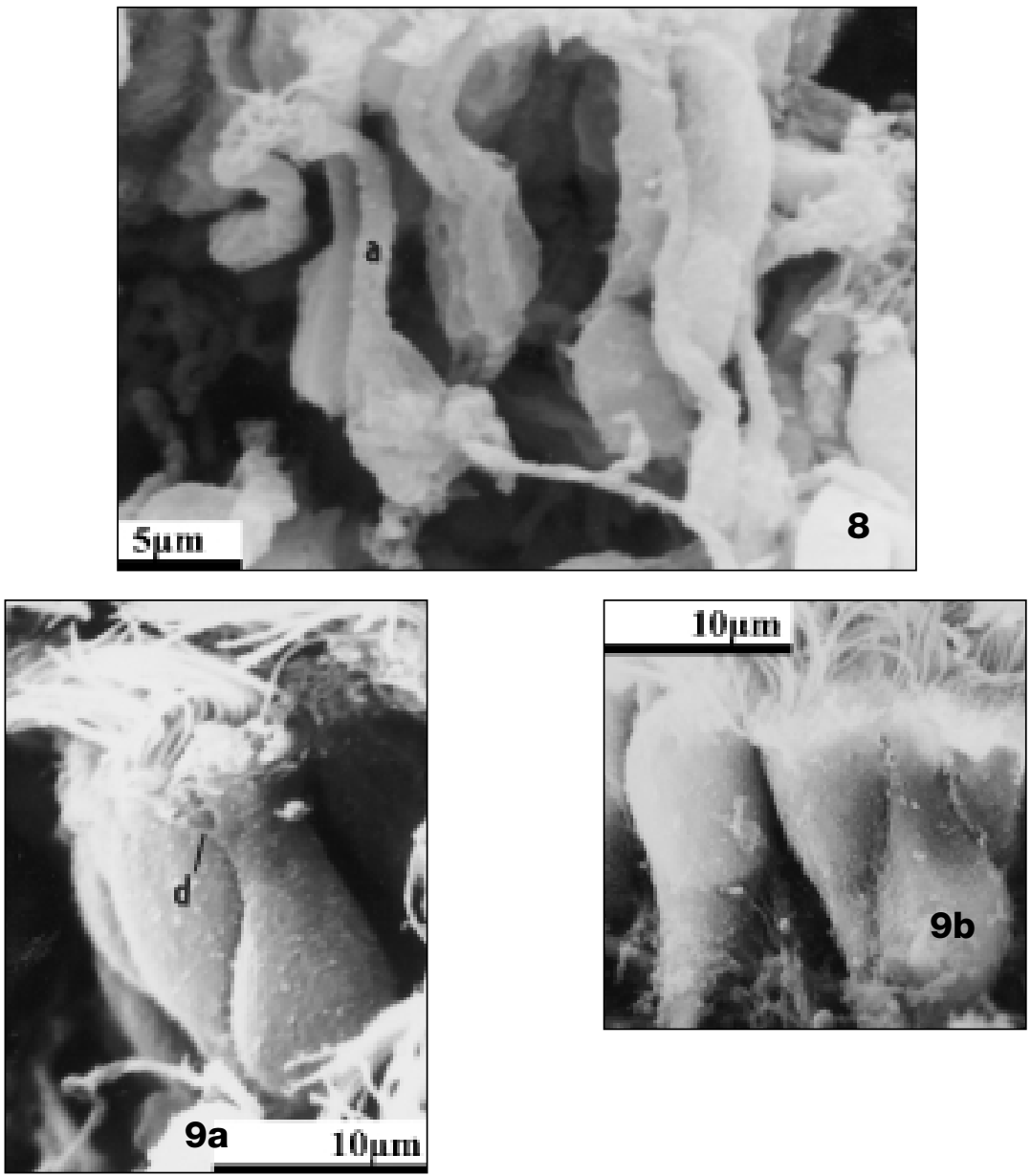

Fig. 8. Pseudo-layered (A) almost one-layered (B) arrangement of the ependymal cells from the third cerebral ventricle in a 120-day-old sheep foetus.

Fig. 9. More regular layers of the ependymal cells from the co-arctation region of the third cerebral ventricle in a 57-day-old goat foetus.

a - proximal (apical) process, $\mathrm{b}$ - basal process, $\mathrm{c}$ - body of the ependymal cell, $\mathrm{d}$ - lamellar projections, AIT adhesio interthalamica 